\title{
Faecal dry weight and potassium are related to faecal sodium and plasma aldosterone in rats chronically fed on varying amounts of sodium or potassium chlorides
}

\author{
BY RICHARD D. MCCABE, MANIS J.SMITH JR AND TERRY M. DWYER \\ The Department of Physiology and Biophysics, The University of Mississippi Medical Center, \\ 2500 North State Street, Jackson, Mississippi 39216-4505, USA
}

(Received 26 July 1993 - Revised 22 November 1993 - Accepted 14 December 1993)

\begin{abstract}
Recent studies have shown that faecal residue (dry weight) and $\mathrm{Na}$ and $\mathrm{K}$ increase with increasing levels of dietary fibre, an effect which may be related to unstirred layers that slow absorption and the flow rate of chyme through the gastrointestinal tract. Salts of $\mathrm{Na}$ are the primary osmotic components of chyme and influence both retention of fluid in the bowel and transit of fluid from the small to the large intestine. The present study examines the chronic effects of dietary $\mathrm{Na}$ and $\mathrm{K}$ intake on faecal $\mathrm{Na}, \mathrm{K}$ and residue excretion. Male Sprague-Dawley rats were given 12-13 g feed/d (control (g/kg): $\mathrm{Na} \mathrm{4,} \mathrm{K} \mathrm{8.5)} \mathrm{for} 1$ week, followed by a 4-week period where $\mathrm{Na}$ or $\mathrm{K}$ intake was altered ( $0.01-3$ times control levels). These diets altered chronic ( $>1$ week) faecal residue excretion and affected $\mathrm{Na}$ and $\mathrm{K}$ excretion by 8-, 310and 2100-fold respectively. Low dietary $\mathrm{Na}$ reduced faecal $\mathrm{Na}$ and residue; $\mathrm{K}$ excretion was doubled during week 1, but fell over weeks 2-4 despite a 4-5-fold increase in plasma aldosterone. Chronic high dietary $\mathrm{Na}$ increased faecal $\mathrm{Na}$, residue and $\mathrm{K}$ despite a $60 \%$ decrease in plasma aldosterone. Chronic low dietary $\mathrm{K}$ decreased faecal $\mathrm{Na}, \mathrm{K}$ and residue and plasma aldosterone. Chronic high dietary $\mathrm{K}$ did not alter faecal $\mathrm{Na}$ and $\mathrm{K}$ despite increased faecal residue and a 4-5-fold increase in plasma aldosterone. Faecal water was unchanged by diet, paralleling changes in faecal residue. Analyses of the results provide systematic models of chronic regulation of faecal $\mathrm{Na}, \mathrm{K}$ and residue excretions. When plasma aldosterone is low $(<160 \mathrm{ng} / \mathrm{l})$, weekly faecal residue excretion is equal to $3.6 \mathrm{~g}$ (fibre intake was $2.6-2.7 \mathrm{~g} /$ week $)+2.6 \mathrm{~g} / \mathrm{mmol} \mathrm{Na}$, and $\mathrm{K}$ excretion is equal to $0.55 \mathrm{mmol} / \mathrm{mmol} \mathrm{Na}$. When plasma aldosterone is high ( $>1500 \mathrm{ng} / \mathrm{l}$ ) weekly faecal residue excretion is equal to $2 \cdot 3 \mathrm{~g}+2 \cdot 6 \mathrm{~g} / \mathrm{mmol} \mathrm{Na}$, and $\dot{K}$ excretion is equal to $0.7 \mathrm{mmol} /$ week $+0.55 \mathrm{mmol} / \mathrm{mmol} \mathrm{Na}$.
\end{abstract}

Sodium: Potassium: Aldosterone: Faeces: Rat

Recent studies with dietary fibre provide indirect evidence of flow-dependent intestinal absorption. Dietary fibre increases faecal excretion of $\mathrm{Na}, \mathrm{K}$ and a residue composed of the fibre itself, plus carbohydrates and lipids (Eastwood et al. 1980; Murray et al. 1980; Judd \& Trusell, 1981; Spiller et al. 1986; Jeraci \& Van Soest, 1990) in the proportions 7:3 (Brandaru, 1990). Fibre may increase non-fibrous residue excretion by forming a gel adjacent to the small intestinal epithelium which creates a watery barrier (Dietschey et al. 1971; Johnson \& Gee, 1981 ; Fluorie et al. 1984; Fuse et al. 1989). Such 'unstirred layers' can slow the rate of diffusion between chyme and absorptive sites on the small intestinal epithelium so that absorption becomes self-limiting. Thus, a gradient is created where the concentration of nutrients may remain high in chyme but diminishes along the thickness of the unstirred layer, reaching a minimum at the absorptive site. Unstirred layers may permit nutrients to flow through the gastrointestinal tract without being absorbed.

$\mathrm{Na}$ has important roles in intestinal transport and fluid balance. Salts of $\mathrm{Na}$ are the chief osmotic constituents of chyme (Edmonds, 1967; Dietschey et al. 1971). The presence of Na 
and its conjugate anions necessitates retention of water within the lumen since small intestinal absorption is isosmotic (Curran \& Solomon, 1957; Fordtran et al. 1965; Fordtran \& Locklear, 1966). And so, Na salts determine the amounts of fluid contained in the small intestine (Gotch et al. 1957) and transferred from the small to the large intestine (Phillips, 1969; Phillips \& Giller, 1973; Debongie \& Phillips, 1978). Fluid retained in the gastrointestinal tract with $\mathrm{Na}$ can dilute nutrients and limit their entry into unstirred layers, resulting in reduced absorption. This could reduce absorption and increase excretion.

$\mathrm{Na}$ also exerts an important influence on the large intestine's ability to secrete $\mathrm{K}$. The lumen of the colon has a negative electrical potential which is established by active $\mathrm{Na}$ absorption and largely determines the rate of colonic $\mathrm{K}$ secretion (Frizzell et al. 1976). Intestinal $\mathrm{Na}$ absorption and $\mathrm{K}$ secretion are both dependent on plasma aldosterone. Plasma aldosterone increases $\mathrm{Na}$ entry across the apical membrane of intestinal epithelial cells (Frizzell \& Schultz, 1978) and increases the electrochemical driving force for K exit from colonic epithelial cells (Sandle et al. 1985). In the present study we examine the effects of dietary $\mathrm{NaCl}$ and $\mathrm{KCl}$ on plasma aldosterone and faecal $\mathrm{Na}$ excretion and their relationship with faecal residue and $\mathrm{K}$ excretion.

\section{EXPERIMENTAL METHODS \\ Animals}

Male Sprague-Dawley rats $(250-275 \mathrm{~g})$ from a colony maintained by The University of Mississippi Medical Center were isolated in stainless-steel metabolism cages (Lab Products, Maywood, NJ, USA). The cages had a stainless-steel screen on the bottom through which excreta passed into a collection funnel which directed urine into a collection bottle. The funnel was modified by the addition of a fine stainless-steel mesh over the collection port to prevent faeces from entering the urine collection bottle. Drinking water was dispensed from a calibrated bottle (Lab Products) which the rat could operate. Measured amounts of feed were dispensed by a stainless-steel feeder (Lab Products). Procedures were approved by the Institutional Animal Care and Use Committee.

\section{Diets}

Five diets were used in the present study. Four of these diets (control, high $\mathrm{Na}$, low $\mathrm{Na}$ and high $\mathrm{K}$ ) were based on a commercial diet (4881C-B for control, high $\mathrm{Na}$ and high $\mathrm{K}$, and $4881 \mathrm{C}$ for low Na) obtained from Ralston Purina (Richmond, IN, USA). The basal diet consisted of (g/ kg): dextrin 427 (436.5 for the low-Na diet), casein (unpurified) 210, sucrose 150, maize oil 50, lard 50, Ralston Purina mineral mix without $\mathrm{Na} 50$, solka floc 30, Ralston Purina vitamin mix 20, $\mathrm{NaCl} 9.5$ ( 0 for the low-Na diet), choline chloride 2, DL-methionine 1.5. Purina was unable to provide a low-K diet as most of the dietary $\mathrm{K}$ came from components other than the mineral mix. Therefore, a low-K diet from ICN $(904665$; ICN, Cleveland, OH, USA) was substituted. The low-K diet contained: sucrose $419 \cdot 8$, maize starch 215.8, purified casein (high-N) 297, butter $34 \cdot 6, \mathrm{CaCO}_{3} 12 \cdot 9, \mathrm{NaCl} 9 \cdot 9$, and ICN vitamin diet fortification mixture 10. The actual $\mathrm{Na}$ and $\mathrm{K}$ values of the diets were determined by chemical analysis (see p. 327) and were $(\mathrm{g} / \mathrm{kg}): \mathrm{Na} 4, \mathrm{~K} 8 \cdot 5$, for control and high-Na or $-\mathrm{K}$ diets; $\mathrm{Na} 0 \cdot 3, \mathrm{~K} 8 \cdot 5$, for the low-Na diet; $\mathrm{Na} 4, \mathrm{~K} 0 \cdot 06$, for the low-K diet.

The animals were fed on the control diet for 2 weeks before receiving the test diets. The first week of this control period served to adapt the rats to the diet. Control excretion rates were established from collections made during the second week of the control period. The animals were then fed on one of the test diets for 4 weeks. Animals were allowed ad lib. access to either deionized water (control, low- $\mathrm{Na}$ and low-K groups), $150 \mathrm{mmol} \mathrm{NaCl} / 1$ (high-Na diet) or $150 \mathrm{mmol} \mathrm{KCl} / 1$ (high-K diet). Feed was limited to $12-13 \mathrm{~g} / \mathrm{d}$ (weighed 
to $1 \mathrm{mg}$ ), because the high-K group consumed no more than this in preliminary experiments. No unused food remained for any rat on any day of the excretion experiments reported here. Monitoring of consumption showed that changes in dietary $\mathrm{Na}$ did not alter $\mathrm{K}$ intake and changes in dietary $\mathrm{K}$ did not alter $\mathrm{Na}$ intake.

\section{Analytical methods}

All waste was collected, processed and analysed. Feed was also analysed for $\mathrm{Na}$ and $\mathrm{K}$. Faeces were separated from non-faecal solid wastes, chiefly food crumbs, with a spatula and each pellet was brushed free of other solid waste using a sable brush. Pellets were counted and collected with non-faecal solid waste in separate crucibles that had been tared after drying. Crucibles were dried under partial vacuum $(40 \mathrm{KPa})$ for $24 \mathrm{~h}$ at $90^{\circ}$ and $1 \mathrm{~h}$ at $110^{\circ}$, allowed to cool, and reweighed to determine faecal dry weight (residue). Faecal residue was ashed for $24 \mathrm{~h}$ at approximately $430^{\circ}$ and the contents of each crucible digested in $1 \mathrm{ml}$ analytical grade $\mathrm{HNO}_{3}(700 \mathrm{ml} / 1 ;$ J. T. Baker, Phillipsburg, NJ, USA). Samples of feed of known weight were ashed in a similar manner and resuspended in a known amount of $\mathrm{HNO}_{3}$. The contents of each crucible were washed into a polycarbonate centrifuge tube and diluted with deionized water $(5 \mathrm{ml}$ per crucible for low- $\mathrm{Na}$ and $-\mathrm{K}$ diets and $50 \mathrm{ml}$ per crucible for other diets; one crucible per week was needed for each rat on low-Na or low$\mathrm{K}$ diets, while two to five crucibles per week were needed for each rat on other diets).

The $\mathrm{Na}$ and $\mathrm{K}$ contents of extracts of faeces and non-faecal solid waste and of centrifuged urine samples were determined by flame photometry using an Instrumentation Laboratories Model 343 (Lexington, MA, USA) flame photometer. The Na and K contents of non-faecal solid waste were subtracted from the corresponding $\mathrm{Na}$ and $\mathrm{K}$ contents of the feed to determine the actual $\mathrm{Na}$ and $\mathrm{K}$ intakes. There was no detectable background contamination in the crucibles or $\mathrm{HNO}_{3}$.

Parallel studies were conducted to measure plasma aldosterone and electrolytes, muscle ion and water contents, faecal water content, and weight gain. In these studies one group of rats received the control diet for 4 weeks to serve as a time-control. The other groups received one of the test diets for 4 weeks. The adapted or time-control rats were then isolated in a cage containing gauze pads soaked in halothane. When anaesthesia was verified by the absence of the deep tendon reflex and slowing of the corneal reflex, 3-5 ml plasma was collected by cardiac puncture in $100 \mathrm{U}$ ammonium heparin for analysis by flame photometry, by vapour pressure osmometry (Wescor Model 1710, Logan, UT, USA), and by specific radioimmunoassay for plasma aldosterone. The right anterior tibialis was then removed, trimmed to isolate the muscle body from ligaments and muscle sheath, placed in a $10 \mathrm{~mm} \times 75 \mathrm{~mm}$ glass tube that had been tared after drying, weighed, dried for $24 \mathrm{~h}$ at $90^{\circ}$ and $1 \mathrm{~h}$ at $110^{\circ}$ under partial vacuum, as described previously for faeces, and reweighed. $\mathrm{HNO}_{3}(1 \mathrm{ml})$ was added to each tube and the tubes were tightly sealed with a double layer of Teflon tape and allowed to digest overnight. The tubes were further diluted with $1 \mathrm{ml}$ distilled water and contents analysed by flame photometry. Faecal water was determined from fresh faeces, to avoid water loss. After the 4-week adaptation period, animals were isolated and observed until they defaecated. The pellet was immediately collected into a tared vial and weighed and then dried, as described for other faecal samples, and reweighed.

\section{Statistics}

The statistical significance of changes in faecal $\mathrm{Na}, \mathrm{K}$ and residue was determined using Dunnett's test for repeated measures (Dunnett, 1955). Plasma $\mathrm{Na}$ and $\mathrm{K}$ concentrations, osmolarity, packed cell volume and aldosterone, and muscle $\mathrm{Na}$ and $\mathrm{K}$ concentrations were compared using Dunnett's test for repeated measures. The effects of $\mathrm{K}$ on cumulative $\mathrm{Na}$ 
and $\mathrm{K}$ excretion were evaluated using a paired-sample Student's $t$ test. Relationships between faecal $\mathrm{Na}, \mathrm{K}$ and residue excretion were analysed using simple linear regression. The $95 \%$ confidence intervals (CI) of the intercepts were calculated as the $95 \%$ confidence belts at the intercepts (Zar, 1974). All tests of significance employed the two-sided assumption; $P<0.05$ was considered significant.

\section{RESULTS}

Under control conditions faecal excretion accounted for 20 (SE 1) \% of Na and 10 (SE 1) \% of $\mathrm{K}$ excretion. In previous studies with rats faecal excretion accounted for $16-23 \%$ of $\mathrm{Na}$ and 10-11\% of K excretion (Sealey et al. 1970; Mohring \& Mohring, 1972; Chabert et al. 1984).

\section{Dietary $\mathrm{Na}$}

After 4 weeks on the high-Na diet there was a 1.6-fold increase in faecal $\mathrm{Na}$ excretion (Fig. 1); 4 weeks on the low-Na diet decreased faecal Na excretion by $99 \%$. During the final week the high-Na group consumed 45.8 (SE 0.6) mmol Na and excreted 44.6 (SE 3.4) mmol $\mathrm{Na}$, while the low- $\mathrm{Na}$ group consumed 0.15 (SE 0.00 ) mmol $\mathrm{Na}$ and excreted 0.20 (SE 0.10$)$ mmol $\mathrm{Na}$. Urinary $\mathrm{Na}$ excretion quadrupled on the high-Na diet and fell by $97 \%$ on the low-Na diet (Table 1). Faecal excretion accounted for 12 (SE 2) \% of total Na excretion during $\mathrm{Na}$ repletion and 9 (SE 2)\% during $\mathrm{Na}$ depletion.

Dietary $\mathrm{Na}$ also influenced $\mathrm{K}$ excretion. The high-Na diet caused sustained increases in both faecal K (Fig. 2) and urinary K (Table 1) excretion, although K intake was constant. We normalized these $K$ excretion values by subtracting the control value for weekly excretion rate from the excretion rate during each experimental week and a cumulative value from the sum of values for the four experimental weeks was obtained. Results (Fig. 3) show that the high- $\mathrm{Na}$ diet caused a negative $\mathrm{K}$ balance. This $\mathrm{K}$ loss was primarily accounted for by a weight loss of 5 (SE 12) g compared with a weight gain of 60 (SE 8) $\mathrm{g}$ for the controls (Table 2). The $65 \mathrm{~g}$ difference accounts for $5.5-5.9 \mathrm{mmol} \mathrm{K}$ with tissue $\mathrm{K}$ values of $84-90 \mu \mathrm{mol} / \mathrm{g}$ (Table 2 ), $60 \%$ of the difference in $\mathrm{K}$ retention. The ability of high salt intake to reduce weight gain has been reported by Sealey et al. (1970). With their ad lib.fed diets, Sealey et al. (1970) also observed weight loss with increased dietary K. In preliminary experiments we found that this effect resulted from reduced consumption and we limited the consumption of all groups to prevent it (see pp. 326-327).

The low-Na diet caused biphasic changes in faecal $\mathrm{K}$ excretion. Faecal $\mathrm{K}$ increased during the first week of $\mathrm{Na}$ depletion (Fig. 2) as observed in acute studies in rabbit (Chabert et al. 1984) and dog (Field et al. 1954). However, this acute effect was actually reversed during chronic $\mathrm{Na}$ depletion since faecal $\mathrm{K}$ excretion during weeks $2-4$ fell below that for controls (Fig. 2). Low dietary Na also produced a kaliuresis (Table 2). Decreased faecal $\mathrm{K}$ excretion quantitatively offset the kaliuresis and $\mathrm{K}$ excretion over the entire study was as expected on the basis of the control values for $\mathrm{K}$ excretion rate (Fig. 3).

\section{Dietary $K$}

The high-K diet had no significant effect on faecal $\mathrm{K}$ excretion, but the low-K diet reduced faecal K excretion by $99.94 \%$ (Fig. 2). Urinary K excretion was tripled on the high-K diet and reduced by over $95 \%$ on the low-K diet (Table 1). During week 4 the high-K group consumed 42.5 (SE 0.3) mmol $\mathrm{K}$ and excreted 39.8 (SE 3.6) $\mathrm{mmol} \mathrm{K}$ and the low-K group consumed 0.13 (SE 0.00 ) mmol $\mathrm{K}$ and excreted 0.65 (SE 0.08 ) $\mathrm{mmol} \mathrm{K}$. Faecal excretion accounted for 5 (SE 2 ) \% of $\mathrm{K}$ excretion on the high-K diet and 2 (SE 2 ) \% of $\mathrm{K}$ excretion on the low-K diet. 


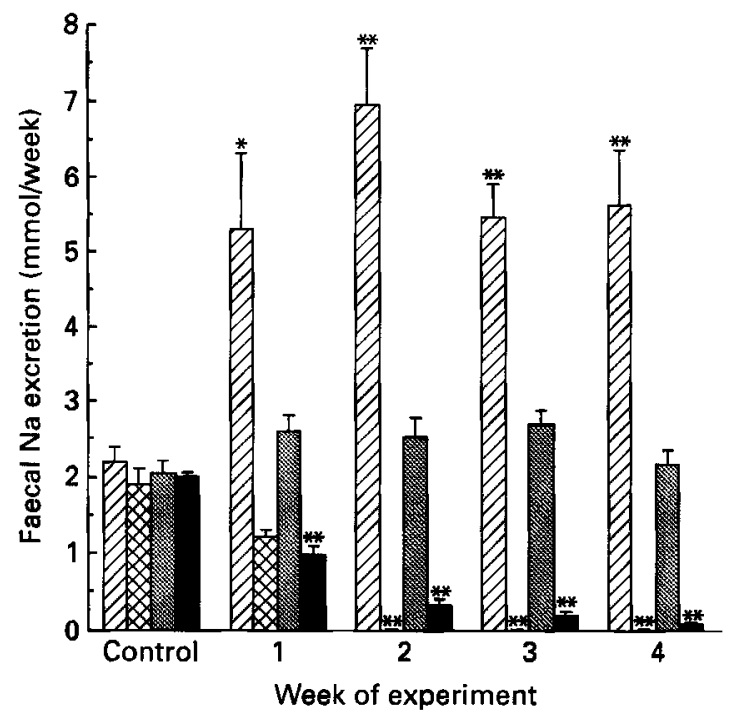

Fig. 1. The rate of faecal sodium excretion as a function of time before and after changing from normal (control) to high or low dietary $\mathrm{KCl}$ or $\mathrm{NaCl}$ : $(\mathbb{Z})$, high $\mathrm{Na}$; $(\otimes)$, low $\mathrm{Na}$; (圈), high $\mathrm{K}$; $(\mathbf{C})$, low $\mathrm{K}$. Values are means with their standard errors, represented by vertical bars, for four groups of four rats each. Mean values were significantly different from those for the control week (two-sided Dunnett's test for repeated measures): ${ }^{*} P<0.05 ;{ }^{* *} P<0.01$. For details of dietary regimen and procedures, see pp. 326-328.

Table 1. Urinary excretion of minerals ( $\mathrm{mmol} /$ week) by four groups of rats before and after changes in dietary sodium or potassium $\dagger$

(Mean values with their standard errors)

\begin{tabular}{|c|c|c|c|c|c|c|c|c|}
\hline \multirow[t]{2}{*}{ Diet... } & \multicolumn{2}{|c|}{ High $\mathrm{Na}$} & \multicolumn{2}{|c|}{ Low $\mathrm{Na}$} & \multicolumn{2}{|c|}{ High $\mathbf{K}$} & \multicolumn{2}{|c|}{ Low $\mathrm{K}$} \\
\hline & Mean & $\mathbf{S E}$ & Mean & $\mathbf{S E}$ & Mean & $\mathbf{S E}$ & Mean & $\mathbf{S E}$ \\
\hline \multicolumn{9}{|l|}{ Control } \\
\hline Na excretion & 8.4 & 0.8 & $7 \cdot 8$ & 0.2 & $7 \cdot 8$ & $0-2$ & $8 \cdot 1$ & 0.4 \\
\hline \multicolumn{8}{|l|}{ Week 1} & 0.7 \\
\hline $\mathrm{Na}$ excretion & $27 \cdot 2^{*}$ & $3 \cdot 0$ & $3 \cdot 8^{* *}$ & 0.9 & $8 \cdot 9^{*}$ & 0.5 & $9 \cdot 2$ & 0.6 \\
\hline $\mathbf{K}$ excretion & 10.6 & 0.7 & $11 \cdot 1^{*}$ & 0.5 & $38 \cdot 5^{* *}$ & $4 \cdot 4$ & $2 \cdot 2^{* *}$ & 0.3 \\
\hline \multicolumn{9}{|l|}{ Week 2} \\
\hline $\mathrm{Na}$ excretion & $43 \cdot 0^{* *}$ & $8 \cdot 0$ & $0 \cdot 7^{* *}$ & 0.2 & $8 \cdot 2$ & $0 \cdot 6$ & $9 \cdot 5^{*}$ & $0 \cdot 3$ \\
\hline $\mathrm{K}$ excretion & $17 \cdot 4^{*}$ & $1 \cdot 3$ & $13-4$ & $2-4$ & $39 \cdot 4^{* *}$ & $2 \cdot 6$ & $0 \cdot 8^{* *}$ & $0 \cdot 3$ \\
\hline \multicolumn{9}{|l|}{ Week 3} \\
\hline $\mathrm{Na}$ excretion & $38 \cdot 7 * *$ & 3.8 & $0 \cdot 3^{* *}$ & $0 \cdot 1$ & $7 \cdot 4$ & 0.7 & $10 \cdot 4^{*}$ & $0 \cdot 3$ \\
\hline $\mathbf{K}$ excretion & $15 \cdot 7$ & 1.7 & $13 \cdot 1$ & $1 \cdot 4$ & $36 \cdot 5^{* *}$ & $2 \cdot 3$ & $0 \cdot 7^{* *}$ & $0 \cdot 1$ \\
\hline \multicolumn{9}{|l|}{ Week 4} \\
\hline Na excretion & $32 \cdot 9 * *$ & $2 \cdot 9$ & $0.2 * *$ & $0 \cdot 1$ & 7.9 & 0.6 & $10 \cdot 4^{*}$ & 0.4 \\
\hline K excretion & $13 \cdot 1$ & $2 \cdot 3$ & $13 \cdot 4$ & $1 \cdot 0$ & $35 \cdot 1 * *$ & $4 \cdot 1$ & $0 \cdot 6^{* *}$ & $0 \cdot 1$ \\
\hline
\end{tabular}

Mean value was significantly different from that for the same group during the control week (two-sided Dunnett's test for repeated measures): ${ }^{*} P<0.05 ;{ }^{*} P<0.01$.

$\dagger$ For details of dietary regimen and procedures, see pp. 326-328. 


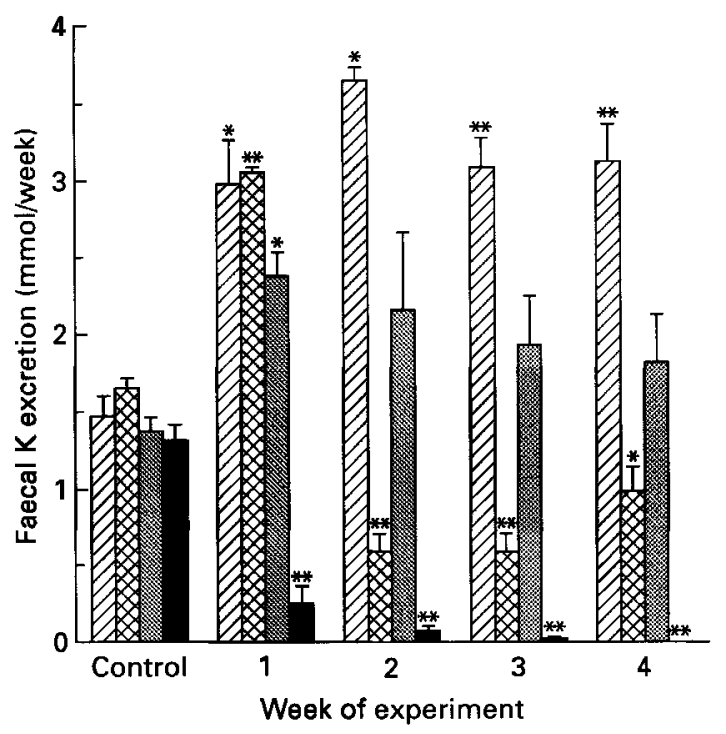

Fig. 2. The rate of faecal $\mathrm{K}$ excretion as a function of time before and after changing from normal (control) to high or low dietary $\mathrm{KCl}$ or $\mathrm{NaCl}:(\square)$, high $\mathrm{Na} ;(\otimes)$, low $\mathrm{Na}$; (圈), high $\mathrm{K} ;(\mathbf{\square})$, low $\mathrm{K}$. Values are means with their standard errors, represented by vertical bars, for four groups of four rats each. Mean values were significantly different from those for the control week (two-sided Dunnett's test for repeated measures): ${ }^{*} P<0.05 ;{ }^{* *} P<0-01$. For details of dietary regimen and procedures, see pp. 326-328.

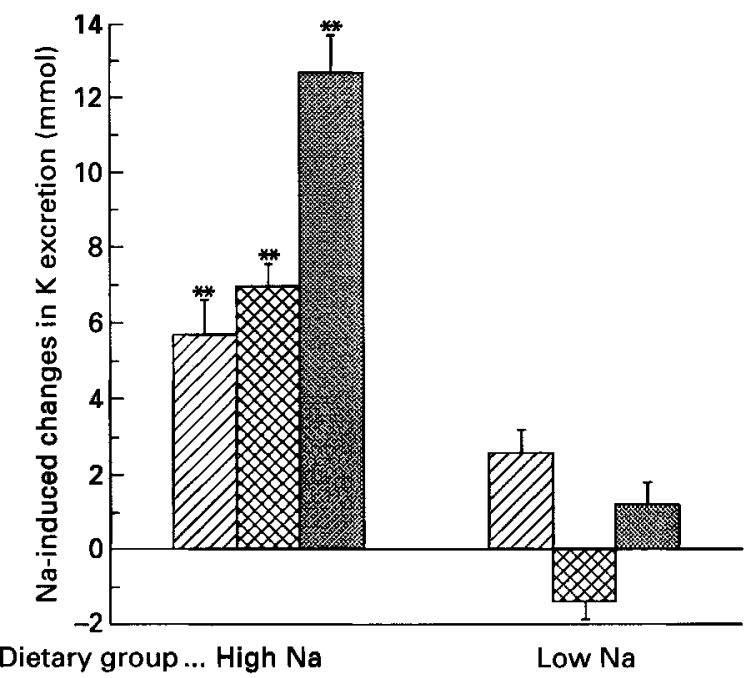

Fig. 3. The effects of dietary $\mathrm{Na}$ on $\mathrm{K}$ balance derived from the differences between control and experimental $\mathrm{K}$ excretion rates (sum of values for the 4-week course of the experimental period): ( $\square$ ), Urinary $\mathrm{K}$; (B), faecal $\mathrm{K}$; (圆), total $\mathrm{K}$ excretion. Values are means with their standard errors of the difference, represented by vertical bars, for two groups of four rats each. Mean values were significantly different from zero (two-sided, paired Student's $t$ test) : ${ }^{* *} P<0.01$. For details of dietary regimen and procedures, see pp. 326-328.

Changes in dietary $\mathrm{K}$ also caused changes in $\mathrm{Na}$ excretion. Urinary $\mathrm{Na}$ excretion was increased in the first week of high $\mathrm{K}$ intake (Table 1). Although faecal Na was not significantly increased during any particular week (Fig. 1) each rat excreted more faecal Na in 3 weeks of the 4 weeks of $\mathrm{K}$ repletion, resulting in an excess faecal $\mathrm{Na}$ excretion of 1.9 
Table 2. Plasma electrolytes and aldosterone, muscle electrolytes, faecal water content and weight gained by five groups of rats fed on differing diets for 4 weeks $\dagger$

(Mean values with their standard errors)

\begin{tabular}{|c|c|c|c|c|c|c|c|c|c|c|}
\hline \multirow[t]{2}{*}{ Diet ... } & \multicolumn{2}{|c|}{ Control } & \multicolumn{2}{|c|}{ High $\mathrm{Na}$} & \multicolumn{2}{|c|}{ Low $\mathrm{Na}$} & \multicolumn{2}{|c|}{ High $\mathbf{K}$} & \multicolumn{2}{|c|}{ Low $\mathrm{K}$} \\
\hline & Mean & $\mathbf{S E}$ & Mean & SE & Mean & SE & Mean & SE & Mean & SE \\
\hline \multicolumn{11}{|l|}{ Plasma } \\
\hline $\mathrm{Na}(\mathrm{mmol} / \mathrm{l})$ & 145 & 2 & 146 & 2 & 147 & 31 & 144 & 5 & 147 & 4 \\
\hline $\mathrm{K}(\mathrm{mmol} / \mathrm{l})$ & 4.9 & $0 \cdot 3$ & $5 \cdot 1$ & $0 \cdot 1$ & $5 \cdot 2$ & $0 \cdot 2$ & $6 \cdot 3$ & $0 \cdot 6^{* *}$ & $3 \cdot 4^{* *}$ & 0.4 \\
\hline $\begin{array}{l}\text { Osmolarity } \\
\text { (mosm/kg) }\end{array}$ & 308 & 3 & 309 & 5 & 305 & 7 & 306 & 5 & 307 & 4 \\
\hline $\begin{array}{l}\text { Aldosterone } \\
\text { (ng/l) }\end{array}$ & 345 & 76 & $142^{* *}$ & 16 & $1870^{* *}$ & 640 & $1534^{* *}$ & 416 & $158^{* *}$ & 46 \\
\hline$n$ & \multicolumn{2}{|c|}{ (5) } & \multicolumn{2}{|c|}{ (7) } & \multicolumn{2}{|c|}{ (7) } & \multicolumn{2}{|c|}{ (3) } & \multicolumn{2}{|c|}{ (6) } \\
\hline Muscle & & & & & & & & & & \\
\hline $\mathrm{Na}(\mu \mathrm{mol} / \mathrm{g})$ & 27 & 1 & 28 & 3 & $19^{* *}$ & 1 & $18 * *$ & 0 & 25 & 1 \\
\hline $\mathrm{K}(\mu \mathrm{mol} / \mathrm{g})$ & 104 & 2 & 106 & 3 & 108 & 3 & $121^{* *}$ & 1 & $98 * *$ & 1 \\
\hline $\begin{array}{l}\text { Water content } \\
(\mathrm{mg} / \mathrm{g})\end{array}$ & 647 & 14 & 656 & 29 & 665 & 13 & 657 & 15 & 620 & 6 \\
\hline$n$ & \multicolumn{2}{|c|}{ (8) } & \multicolumn{2}{|c|}{ (6) } & \multicolumn{2}{|c|}{ (6) } & \multicolumn{2}{|c|}{ (7) } & \multicolumn{2}{|c|}{ (4) } \\
\hline \multicolumn{11}{|l|}{ Faeces } \\
\hline $\begin{array}{l}\text { Water content } \\
(\mathrm{mg} / \mathrm{g})\end{array}$ & 556 & 35 & 511 & 36 & 515 & 24 & 493 & 45 & 460 & 30 \\
\hline$n$ & \multicolumn{2}{|c|}{ (8) } & \multicolumn{2}{|c|}{ (6) } & \multicolumn{2}{|c|}{ (6) } & \multicolumn{2}{|c|}{ (6) } & \multicolumn{2}{|c|}{ (6) } \\
\hline $\begin{array}{l}\text { Wet gain }(\mathrm{g}) \\
\quad n\end{array}$ & 75 & 8 & $-5^{*}$ & 12 & 66 & 10 & 59 & 11 & 62 & 10 \\
\hline
\end{tabular}

Mean value was significantly different from control group (two-sided Dunnett's test for repeated measures): ${ }^{*} P<0.05 ;{ }^{* *} P<0.01$.

$\dagger$ For details of dietary regimen and procedures, see pp. 326-328.

(SE 0.6) mmol over 4 weeks (Fig. 4). This compares with a cumulative increase in urinary $\mathrm{Na}$ excretion of 1.2 (SE $0.6 \mathrm{mmol}$ (Fig. 4) during the same period. A $7 \mu \mathrm{mol} / \mathrm{g}$ decrease in tissue $\mathrm{Na}$ (Table 2) accounts for most of this $\mathrm{Na}$ loss (over $2 \mathrm{mmol}$ for rats weighing in excess of $300 \mathrm{~g}$ ). The low-K diet decreased faecal Na excretion (Fig. 1), but also increased urinary $\mathrm{Na}$ excretion (Table 1) so that there was no cumulative change in total $\mathrm{Na}$ excretion during $\mathrm{K}$ restriction (Fig. 4).

\section{Plasma electrolytes and aldosterone}

The effects of diet on plasma electrolytes and aldosterone are presented in Table 2. Changes in dietary $\mathrm{Na}$ did not measurably alter plasma $\mathrm{K}$ and $\mathrm{Na}$ concentrations, osmolarity, or packed cell volume after 4 weeks. Increased dietary $\mathrm{K}$ increased plasma $\mathrm{K}$ concentrations, and decreased dietary $\mathrm{K}$ decreased plasma $\mathrm{K}$ concentrations (Table 2 ). Plasma aldosterone was strongly influenced by diet. Both low-Na and high-K diets increased plasma aldosterone by 4-5-fold, and both high-Na and low-K diets reduced plasma aldosterone by at least half (Table 2).

\section{Faecal residue and water}

Dietary $\mathrm{Na}$ and $\mathrm{K}$ also caused changes in faecal residue. These effects are presented in Fig. 5. The high-Na and high-K diets approximately doubled faecal residue, while the low-Na and low-K diets reduced faecal residue by over two-thirds (Fig. 5). Except for the low-K group, these changes were significant only after week 1 (Fig. 5). Since faecal water evaporates rapidly, we determined the faecal water contents $(\mathrm{mg} / \mathrm{g})$ of the various diets in 


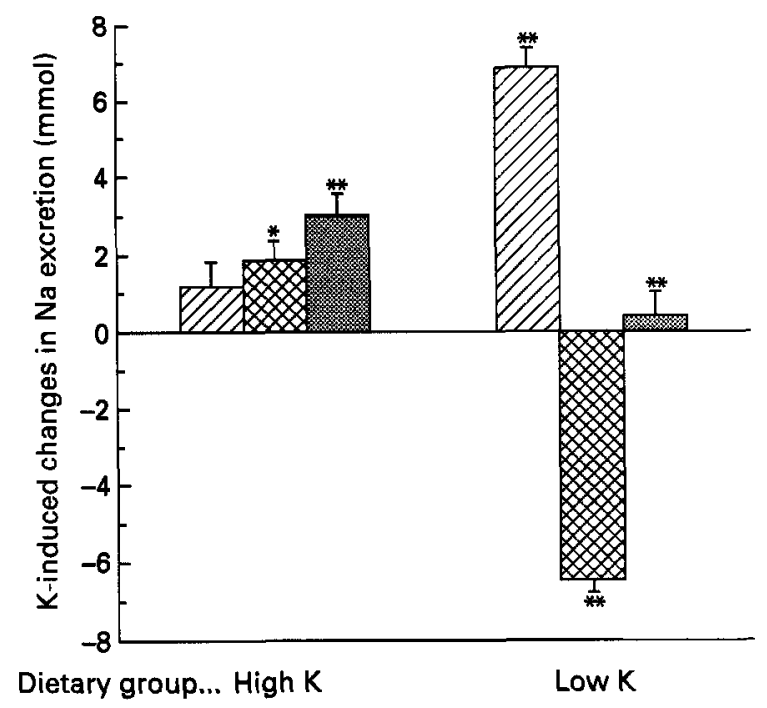

Fig. 4. The effects of dietary $\mathrm{K}$ on $\mathrm{Na}$ balance derived from the differences between control and experimental $\mathrm{Na}$ excretion rates (sum of values for the 4-week course of the experimental period): ( $\square)$, Urinary $\mathrm{Na}$; ( $\square)$, faecal $\mathrm{Na}$; (南), total Na excretion. Values are means with their standard errors of the difference, represented by vertical bars, for two groups of four rats each. Mean values were significantly different from zero (two-sided, paired, Student's $t$-test): ${ }^{*} P<0.05 ;{ }^{* *} P<0.01$. For details of dietary regimen and procedures, see pp. $326-328$.

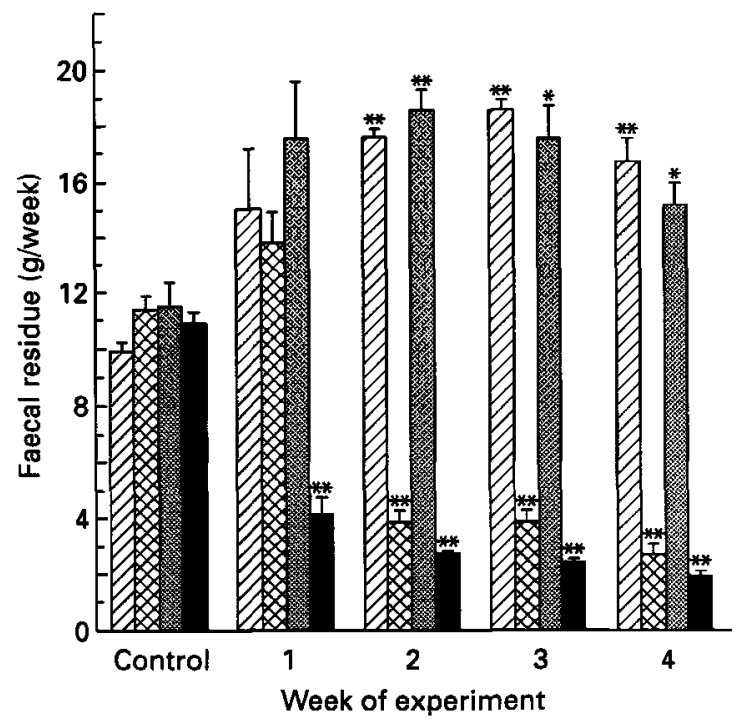

Fig. 5. The rate of faecal dry weight (residue) excretion as a function of time before and after changing from normal to high or low dietary $\mathrm{KCl}$ or $\mathrm{NaCl}$ : $(\square)$, high $\mathrm{Na}$; (因), low $\mathrm{Na}$; (图), high $\mathrm{K}$; ( $\mathbf{Z}$ ), low $\mathrm{K}$. Values are means with their standard errors, represented by vertical bars, for four groups of four rats. Mean values were significantly different from those during the control week (two-sided Dunnett's test for repeated measures): ${ }^{*} P<0.05 ;{ }^{* *} P<0.01$. For details of dietary regimen and procedures, see pp. $326-328$. 
separate experiments. Fresh faecal wet weight $(\mathrm{mg} / \mathrm{g})$ was unaltered by diet (Table 2), indicating that changes in faecal water excretion paralleled the changes in faecal residue (Fig. 5).

\section{DISCUSSION}

Previous studies of the effects of dietary salts on faecal $\mathrm{Na}$ and $\mathrm{K}$ excretion focused primarily on the acute effects of these salts. We found important differences between the chronic and acute effects of changes in dietary salts. For example, acute $\mathrm{Na}$ restriction (1 week) was known to increase faecal $\mathrm{K}$ concentration or $\mathrm{K}: \mathrm{Na}$ ratio which could result in increased faecal K excretion (Field et al. 1954; Edmonds, 1967; Charron et al. 1974). We also observed this response during the acute phase of adaptation (Fig. 2). However, the opposite result was seen during chronic adaptation (Fig. 2) because the volume of faeces was reduced, despite a high faecal $\mathrm{K}: \mathrm{Na}$ ratio. In the present discussion we present models to account for the chronic effects of dietary $\mathrm{Na}$ and $\mathrm{K}$ on faecal excretion and as a basis for further studies.

Analysis of the results of the present study provide an initial model to account for chronic faecal residue excretion. According to this model faecal residue excretion is the sum of an intercept, representing primarily fibre intake, plus non-fibrous excretion which varies with faecal $\mathrm{Na}$ excretion and plasma aldosterone. The relationships for high ( $\geqslant 1500 \mathrm{ng} / \mathrm{l})$ and low ( $\leqslant 160 \mathrm{ng} / \mathrm{l})$ plasma aldosterone values are presented in Fig. 6 . According to these relationships residue excretion is equal to $2 \cdot 3 \mathrm{~g} /$ week $(95 \% \mathrm{CI} 1 \cdot 8,2 \cdot 7) \mathrm{plus} 2.6 \mathrm{~g} / \mathrm{mmol} \mathrm{Na}$ $(95 \%$ CI $2 \cdot 3,2 \cdot 7)$ when plasma aldosterone was low (Table 2$)$ and $3 \cdot 6 \mathrm{~g} /$ week $(95 \% \mathrm{CI} 3 \cdot 3$, $3.9)$ plus $5 \cdot 4 \mathrm{~g} / \mathrm{mmol} \mathrm{Na}(95 \% \mathrm{CI} 5 \cdot 1,5 \cdot 6)$ when plasma aldosterone was high. The high-K and low-Na groups received 2.6-2.7 g solka floc/week, accounting for three-quarters of the high plasma aldosterone intercept. The residual portion of that intercept may result from other indigestible components within the semi-purified diet or from another factor.

The slope of the faecal residue $v$. Na relationship may result from the effects of $\mathrm{Na}$ salts on small intestinal fluid balance. The small intestine cannot establish a strong osmotic gradient (Field et al. 1954; Edmonds, 1967; Phillips, 1969; Phillips \& Giller, 1973; Debongie \& Phillips, 1978) so that $\mathrm{Na}$ and conjugate anions in transit cause fluid to be retained within the gastrointestinal tract (Gotch et al. 1957). The fluids retained can dilute nutrients, reducing their rate of entry into an unstirred layer which apparently limits intestinal absorption (Dietschey et al. 1971; Johnson \& Gee, 1981; Fluorie et al. 1984; Fuse et al. 1989; Edwards, 1990). The colon absorbs most of the $\mathrm{Na}$ leaving the small intestine and concentrates the remaining osmotic particles (Edmonds, 1967; Phillips, 1969; Phillips \& Giller, 1973; Debongie \& Phillips, 1978), but does not participate materially in digestion or absorption of the carbohydrates and lipids that account gravimetrically for the substance of non-fibrous faecal residue (Bandrau, 1990). Other factors contributing to the faecal residue $v$. Na relationship may include dilution of digestive enzymes, micelles, or other constituents of chyme that aid in the overall digestive process. The effect of aldosterone on the faecal residue $v$. Na relationship could reflect colonic extraction of $\mathrm{Na}$, since the colon primarily mediates the aldosterone-induced dilution of $\mathrm{Na}$ that occurs within the gastrointestinal tract (Edmonds, 1967).

Analysis of the data from the present study also yields the first quantitative model of chronic faecal $\mathrm{K}$ excretion. According to this model, faecal $\mathrm{K}$ excretion is related to faecal $\mathrm{Na}$ excretion and plasma aldosterone (Fig. 7). When plasma aldosterone is low, faecal $\mathrm{K}$ excretion is equal to $0.55 \mathrm{mmol} \mathrm{K} / \mathrm{mmol} \mathrm{Na}(95 \% \mathrm{CI} 0.54,0.56)$. When plasma aldosterone is high the relationship between faecal $\mathrm{K}$ and $\mathrm{Na}$ excretion was $0.55 \mathrm{mmol}$ $\mathrm{K} / \mathrm{mmol} \mathrm{Na}(95 \% \mathrm{CI} 0.48,0.62)$. However, increased plasma aldosterone shifts the 


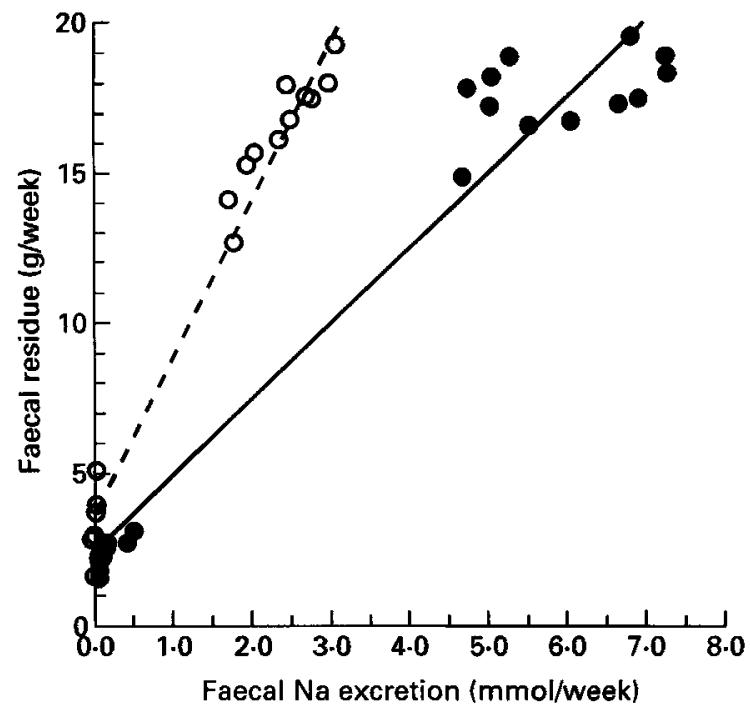

Fig. 6. The relationships between faecal $\mathrm{Na}$ excretion and residue (dry weight) when plasma aldosterone is low ( $\mathrm{O}--\mathrm{O}$, high-Na and low-K diets) or high ( - , low-Na and high-K diets). Values were obtained 2-4 weeks after the diet was changed and analysed by simple linear regression. The low-Na and low-K diets are those points where faecal residue is $<6 \mathrm{~g} /$ week. The high-Na and high-K diets are those points where faecal residue is $>12 \mathrm{~g} /$ week. For details of dietary regimen and procedures, see pp. 326-328.

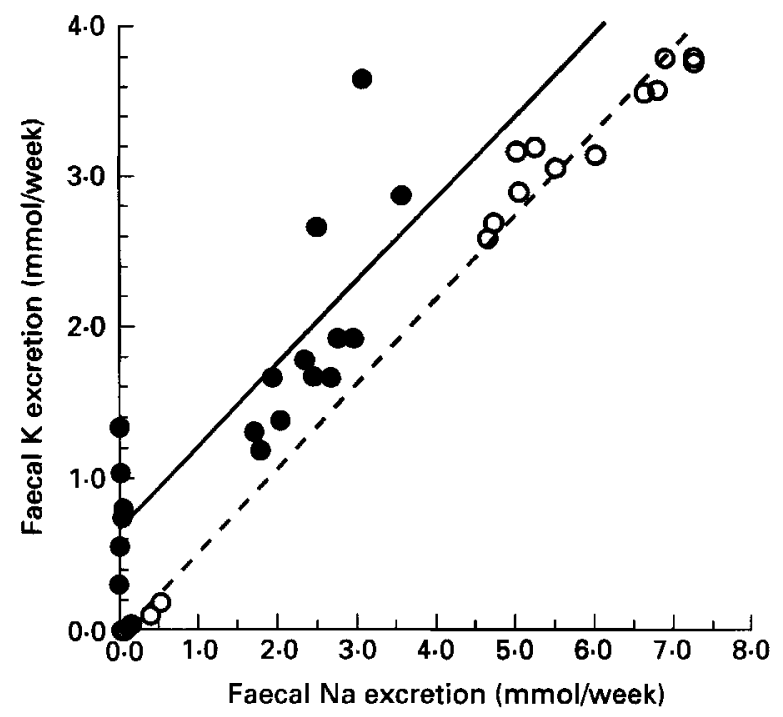

Fig. 7. The relationships between faecal $\mathbf{K}$ excretion and faecal $\mathrm{Na}$ excretion when plasma aldosterone is low ( $\mathrm{O}--\mathrm{O}$, high-Na and low-K diets) or high $(-\quad, \quad l o w-\mathrm{Na}$ and high-K diets). Values were obtained $2-4$ weeks after the diet was changed and analysed by simple linear regression. The low-Na and low-K diets are those points where faecal $\mathrm{Na}$ excretions is $<1 \mathrm{mmol} /$ week. The high- $\mathrm{Na}$ and high-K diets are those points where faecal $\mathrm{Na}$ excretion is $>1 \mathrm{mmol} /$ week. For details of dietary regimen and procedures, see pp. 326-328.

intercept of the faecal $\mathrm{K} v$. Na relationship from $0 \cdot 0(95 \% \mathrm{CI}-0 \cdot 1,0 \cdot 0)$ to $0.7(95 \% \mathrm{CI}$ $0.54,0.80) \mathrm{mmol} \mathrm{K}$. Faecal $\mathrm{K}$ excretion, therefore, is accounted for by a constant faecal $\mathrm{K}: \mathrm{Na}$ ratio with aldosterone increasing faecal $\mathrm{K}$ by a mechanism independent of that ratio.

The faecal $\mathrm{K} v . \mathrm{Na}$ relationship may result from electrical coupling in the exchange of 
$\mathrm{Na}$ and $\mathrm{K}$ in the colon (Wills \& Biagi, 1982). The colon modulates faecal K losses by a combination of active $\mathrm{K}$ secretion and active $\mathrm{K}$ absorption (McCabe et al. 1982, 1984; Wills \& Biagi, 1982; Foster et al. 1986). Colonic K secretion is strongly stimulated by the lumen negative transepithelial potential created by active $\mathrm{Na}$ absorption (Frizzell et al. 1976). This potential depolarizes the apical membrane and hyperpolarizes the basolateral membrane of colonic epithelial cells (Thompson et al. 1982), stimulating apical K exit and inhibiting basolateral $\mathrm{K}$ exit, which augments $\mathrm{K}$ secretion while retarding $\mathrm{K}$ absorption (McCabe et al. 1984). This proposed electrically coupled $\mathrm{K}-\mathrm{Na}$ exchange could explain why plasma aldosterone, which stimulates colonic $\mathrm{Na}$ absorption (Frizzell \& Schultz, 1978), does not entirely predict the chronic changes in faecal $\mathrm{K}$ excretion. Aldosteroneinduced stimulation of colonic $\mathrm{Na}$ absorption can inhibit the $\mathrm{K}-\mathrm{Na}$ exchange by reducing available $\mathrm{Na}$. However, aldosterone also exerts a stimulatory effect on faecal $\mathrm{K}$ excretion independent of faecal $\mathrm{Na}$ excretion (i.e. the intercept). This effect is probably caused by aldosterone-mediated increases in the apical membrane $\mathrm{K}$ permeability and the intracellular $\mathrm{K}$ activity (Sandle et al. 1985) due to increased Na, K-ATPase (EC 3.6.1.37) activity (Charney et al. 1975) on the part of colonic epithelial cells.

The relationships we describe are specific for rat; we expect that the various constants will differ from species to species. In humans a small amount of bran chronically increases faecal $\mathrm{Na}$ excretion from 2.02 to $3.62 \mathrm{mmol} / \mathrm{d}$, faecal $\mathrm{K}$ excretion from 10.70 to $18.66 \mathrm{mmol} / \mathrm{d}$, and faecal residue from 26.1 to $42.5 \mathrm{~g} / \mathrm{d}$ (Eastwood et al. 1980). If we correlate data from this human study, the faecal residue $v$. Na relationship is $12.9 \mathrm{~g} / \mathrm{mmol}$ $\mathrm{Na}$ without bran and $11.7 \mathrm{~g} / \mathrm{mmol} \mathrm{Na}$ with a bran supplement. Thus, the results from humans are qualitatively similar to those of rats since there was a fairly constant relationship between faecal residue and $\mathrm{Na}$, but these results differ quantitatively in that the constant relating them (the slope) is several times greater in humans than in rats. Similarly, human faecal $\mathrm{K}$ excretion was $5.30 \mathrm{mmol} \mathrm{K} / \mathrm{mmol} \mathrm{Na}$ without a fibre supplement and $5.15 \mathrm{mmol} \mathrm{K} / \mathrm{mmol} \mathrm{Na}$ with a dietary fibre supplement (Eastwood et al. 1980); constant within $3 \%$, but with a slope ten times that of the rat.

Species differences in the faecal $\mathrm{K} v$. $\mathrm{Na}$ relationship reflect the lesser importance of faeces in $\mathrm{Na}$ excretion and the greater importance of faeces in $\mathrm{K}$ excretion in humans than in rats. Western humans eating self-selected diets excrete $15-16 \%$ of their $\mathrm{K}$ intake but only $2 \%$ of their $\mathrm{Na}$ intake in faeces (Holbrook et al. 1984). Rats excrete about $10 \%$ of their $\mathrm{K}$ intake and $20 \%$ of their $\mathrm{Na}$ intake in faeces (Sealey et al. 1970; Mohring \& Mohring, 1972; Chabert et al. 1984). These differences may result from the greater length of the human colon, the paucity of fibre in Western diets or other factors. Another similarity is that hyperaldosteronism increases the human faecal $\mathrm{K}: \mathrm{Na}$ ratio (Charron et al. 1974) as the model would predict. Thus, the fundamental concepts relating residue and $\mathrm{K}$ to $\mathrm{Na}$ appear to hold for humans in retrospective analysis of published data.

Important observations were also made concerning the effects of dietary $\mathrm{K}$ on $\mathrm{Na}$ balance. $\mathrm{K}$ repletion for 4 weeks increased $\mathrm{Na}$ excretion by $3 \cdot 1 \mathrm{mmol}$, although $\mathrm{Na}$ intake remained constant (Fig. 4). Increased $\mathrm{Na}$ excretion and loss of tissue $\mathrm{Na}$ are both known effects of K adaptation (Blanchley et al. 1986; Rabelink et al. 1990). The present study illustrates the quantitative importance of this relationship since the $7 \mu \mathrm{mol} / \mathrm{g}$ wet weight difference in tissue $\mathrm{Na}$ content accounts for at least two-thirds of the $\mathrm{Na}$ loss in a rat weighing about $300 \mathrm{~g}$ by the end of the study. Thus, the present study demonstrates that $\mathrm{K}$-induced 'natriuresis' chiefly results from loss of tissue $\mathrm{Na}$. This may result from activation of $\mathrm{Na}, \mathrm{K}-\mathrm{ATPase}$ (Rabelink et al. 1990) which causes increased $\mathrm{Na}$ extrusion from the cells.

The second key finding about ionic balances is that changes in faecal excretion of $\mathrm{Na}$ and $\mathrm{K}$ did not always resemble the changes in urinary excretion in either direction or relative 
magnitude. Although $\mathrm{K}$ depletion causes natriuresis (Table 1), no change occurs in $\mathrm{Na}$ balance (Fig. 4) because faecal $\mathrm{Na}$ excretion is markedly reduced (Figs. 2 and 4). The $\mathrm{Na}$ loss induced by $\mathrm{K}$ repletion (Fig. 4) was chiefly effected by increased faecal excretion. This contrasts with the fact that basal urinary $\mathrm{Na}$ excretion is four times the basal faecal $\mathrm{Na}$ excretion. These findings show that changes in ion excretion via a given route do not necessarily occur in proportion to the contribution of that route to basal excretion.

These studies were supported by the National Institutes of Health (HL11678 and HL51971) and the Mississippi and Georgia Affiliates, American Heart Association. The authors are grateful for the helpful suggestions and comments of Drs A. C. Guyton, D. B. Young, T. E. Lohemeier, B. Van Vliet and especially Dr. J. A. Achord.

\section{REFERENCES}

Bandaru, S. R. (1990). Effect of types of dietary fiber on fecal mutagens and bacterial enzymes in relation to colon cancer. In New Developments in Dietary Fiber, pp. 159-166 [I. Furda and C. J. Brine, editors]. New York: Plenum Press.

Blanchley, J. D., Crider, B. P. \& Johnson, J. H. (1986). Extrarenal potassium adaptation: role of skeletal muscle. American Journal of Physiology 251, F313-F318.

Chabert, P. R., Guelpa-Decorzent, C., Riondel, A. M. \& Vallotton, M. B. (1984). Effect of spironolactone on electrolytes, renin, ACTH and corticosteroids in the rat. Journal of Steroid Biochemistry 20, $1253-1259$.

Charney, A. N., Kinsley, D., Meyers, L., Giannella, R. A. \& Gots, R. E. (1975). Na, K-activated adenosine triphosphate and intestinal electrolyte transport. Journal of Clinical Investigation 56, 653-660.

Charron, R. C., Leme, C. E., Wilson, D. R., Ing, T. S. \& Wrong, O. M. (1974). The effect of adrenal steroids on stool composition as revealed by in vitro dialysis of feces. Clinical Science 227, 345-350.

Curran, P. F. \& Solomon, A. K. (1957). Ions and water fluxes in the ileum of rats. Journal of General Physiology 41, 143-168.

Debongie, J. C. \& Phillips, S. F. (1978). Capacity of the human colon to absorb fluid. Gastroenterology 74, 698-703.

Dietschey, J. M., Sallee, V. L. \& Wilson, F. A. (1971). Unstirred water layers and absorption across intestinal mucosa. Gastroenterology 61, 932-934.

Dunnett, C. W. (1955). A multiple procedure for comparing several treatments with a control. Journal of the American Statistical Association 50, 1096-1121.

Eastwood, M. A., Mitchell, W. D. \& Pritchard, J. L. (1980). The effect of bran on excretion of faecal cations. Proceedings of the Nutrition Society 35, 78A-79A.

Edmonds, C. J. (1967). The gradient of electrical potential difference and sodium and potassium on the gut contents along the cecum and colon of normal and sodium-depleted rats. Journal of Physiology 193, 571-588.

Edwards, C. (1990). Mechanism of action of dietary fiber on small intestinal absorption and motility. In New Developments in Dietary Fiber, pp. 95-104 [I. Furda and C. J. Brine, editors]. New York: Plenum Press.

Field, H., Dailey, R. E., Boyd, R. S. \& Swell, L. (1954). Effect of restriction of dietary sodium on electrolyte composition of the contents of the terminal ileum. American Journal of Physiology 179, 477-480.

Fluorie, B., Vidon, N., Florent, C. H. \& Bernier, J. H. (1984). Effect of pectin on jejunal glucose absorption in normal man. Gut 25, 936-941.

Fordtran, J. S. \& Locklear, T. W. (1966). Ionic constituents and osmolarity of gastric and small intestinal fluids after eating. American Journal of Digestive Diseases 11, 503-521.

Fordtran, J. S., Rector, F. C., Enton, M. F., Suter, N. \& Kinney, J. (1965). Permeability characteristics of the human small intestine. Journal of Clinical Investigation 44, 1935-1944.

Foster, E. S., Sandle, G. I., Hayslett, J. P. \& Binder, H. J. (1986). Dietary potassium modulates active potassium absorption and secretion in rat distal colon. American Journal of Physiology 251, G619-G626.

Frizzell, R. A., Koch, M. J. \& Schultz, S. G. (1976). Ion transport by rabbit colon: I. Active and passive components. Journal of Membrane Biology 27, 297-316.

Frizzell, R. A. \& Schultz, S. G. (1978). Effects of aldosterone on ion transport by rabbit colon in-vitro. Journal of Membrane Biology 39, 1-26.

Fuse, K., Bamba, T. \& Hoso, S. (1989). Effects of pectin on fatty acid and glucose absorption and unstirred water layer in rat and human intestine. Digestive Diseases and Sciences 34, 1109-1116.

Gotch, F., Nadell, J. \& Edelman, I. S. (1957). Gastrointestinal water and electrolytes. IV. The equilibration of deuterium oxide $\left(\mathrm{D}_{2} \mathrm{O}\right)$ in gastrointestinal contents and the proportion of total body water (TBW) in the gastrointestinal tract. Journal of Clinical Investigation 36, 289-296.

Holbrook, J. T., Patterson, K. Y., Bodner, J. E., Douglas, L. W., Vellon, C., Kelsay, J. L., Mertz, W. \& Smith, J. C. (1984). Sodium and potassium intake and balance in adults consuming self-selected diets. American Journal of Clinical Nutrition 40, 786-793. 
Jeraci, J. L. \& Van Soest, P. J. (1990). Improved methods for analysis of biological characterization of fiber. In New Developments in Dietary Fiber, pp. 145-163 [1. Furda and C. J. Brine, editors]. New York: Plenum Press.

Johnson, I. T. \& Gee, J. M. (1981). Effect of gel-forming food gums on the intestinal unstirred layer and sugar transport in-vitro. Gut 22, 398-403.

Judd, P. A. \& Trusell, S. A. (1981). The effect of rolled oats on blood lipids and fecal steroid excretion in man. American Journal of Clinical Nutrition 34, 2061-2067.

McCabe, R. D., Cooke, H. J. \& Sullivan, L. P. (1982). Potassium transport by rabbit descending colon. American Journal of Physiology 242, C81-C86.

McCabe, R. D., Smith, P. L. \& Sullivan, L. P. (1984). Ion transport by rabbit descending colon: mechanisms of transepithelial potassium transport. American Joumal of Physiology 246, G594 G602.

Mohring, J. \& Mohring, B. (1972). Evaluation of sodium and potassium balance in rats. Journal of Applied Physiology 33, 688-692.

Murray, D., Fleiszer, D., McArdle, A. H. \& Brown, R. A. (1980). Effect of dietary fiber on intestinal mucosal sodium-potassium-activated ATPase. Journal of Surgical Research 29, 135-140.

Phillips, S. F. (1969). Absorption and secretion by the colon. Gastroenterology 56, 566-571.

Phillips, S. F. \& Giller, J. (1973). The contributions of the colon to electrolyte and water conservation in man. Journal of Laboratory and Clinical Medicine 81, 733-746.

Rabelink, T. J., Koomans, H. A., Hene, R. J. \& Dorhout-Mees, E. J. (1990). Early and late adaptations to potassium loading in humans. Kidney International 38, 942-947.

Sandle, G. I., Foster, E., Lewis, S., Binder, H. J. \& Hayslett, J. P. (1985). The electrical basis of enhanced potassium secretion in rat distal colon during dietary potassium loading. Pfiügers Archives 403, 433-439.

Sealey, J. E., Clark, I., Bull, M. B. \& Laragh, J. H. (1970). Potassium balance and the control of renin secretion. Journal of Clinical Investigation 49, 2119-2127.

Spiller, G. A., Story, J. A., Wong, L. G., Nunes, J. D., Alton, M., Petro, M. S., Furomoto, J. D., Whittam, J. H. \& Scala, J. (1986). Effect of increasing levels of hard wheat fiber on fecal weight, minerals, steroids and gastrointestinal transit time in healthy young women. Journal of Nutrition 116, 778-785.

Thompson, S. M., Suzuki, Y. \& Schultz, S. G. (1982). The electrophysiology of rabbit descending colon. II. Current-voltage relations of the apical membrane, the basolateral membrane and the parallel pathways. Journal of Membrane Biology 66, 41-54.

Wills, N. K. \& Biagi, B. (1982). Active potassium transport by rabbit descending colon. Journal of Membrane Biology 64, 195-203.

Zar, J. H. (1974). Simple linear regression. In Biostatistical Analysis, pp. 198-227. Englewood Cliffs: Prentice-Hall. 